\title{
Minimum inhibitory concentrations of penicillin and minocycline for 300 isolates of $N$. gonorrhoeae
}

\author{
M. SHAHIDULLAH AND P. W. GREAVES \\ Special Treatment Centre, Nottingham General Hospital and Public Health Laboratory, Nottingham
}

Despite the fact that penicillin is still the antibiotic of choice for gonorrhoea, the gradual emergence of strains of $N$. gonorrhoeae of decreased sensitivity to penicillin has led to an increasing search for a suitable alternative antibiotic (Willcox, 1974; Schofield and Masterton, 1974; Kousa, Lassus, Järveläinen, and Renkonen, 1974). In view of the conflicting reports on the efficacy of minocycline for this purpose (Duncan, Glicksman, Knox, and Holder, 1971; Pariser and Marino, 1970; Thatcher, Pazin, and Domescik, 1970), a clinical trial was recently carried out at the Nottingham special treatment centre, which showed a cure rate of $\mathbf{9 4 . 1}$ per cent. in cases of uncomplicated gonorrhoea in males (Shahidullah, 1975).

After this trial it was decided to examine a series of isolates of $N$. gonorrhoeae to determine and compare the minimum inhibitory concentrations of minocycline and penicillin. This study reports the findings of this work.

\section{Material and methods}

300 consecutive isolates of $N$. gonorrhoeae from both male and female patients were examined. These had been isolated on Phillips medium (Phillips, Humphrey, Middleton, and Nicol, 1972) and subcultured onto chocolate agar for purity before testing. A 'just opalescent' suspension of the individual strains, prepared in $1 \mathrm{ml}$. of 10 per cent. serum broth medium, was inoculated onto a series of plates of sensitivity test medium. This consisted of Oxoid digest sensitivity test agar enriched with 7 per cent. lysed, defibrinated horse blood and incorporating the following antibiotic concentrations:

$\begin{array}{lllllll}\text { Penicillin G } & 0.01 & 0.05 & 0.1 & 0.25 & 0.5 & \mu \mathrm{g} . / \mathrm{ml} \text {. } \\ \text { Minocycline } & 0.06 & 0.12 & 0.25 & 0.5 & 1.0 & \mu \mathrm{g} . / \mathrm{ml} \text {. }\end{array}$

Each batch of tests was controlled with an Oxford Staphylococcus (MIC penicillin $0.05 \mu \mathrm{g} . / \mathrm{ml}$., minocycline $0.25 \mu \mathrm{g} . / \mathrm{ml}$.) and an antibiotic-free culture plate. The plates were spot inoculated with a standard $3 \mathrm{~mm}$. loopful of the control organism and the test strains and incubated overnight at $37^{\circ} \mathrm{C}$. in an atmosphere of 10 per cent. carbon dioxide. The MIC was read as the lowest concentration of antibiotic which completely inhibited growth.

Received for publication December 4, 1974

\section{Results}

The MICs of penicillin and minocycline for the 300 isolates are shown in the Figure.

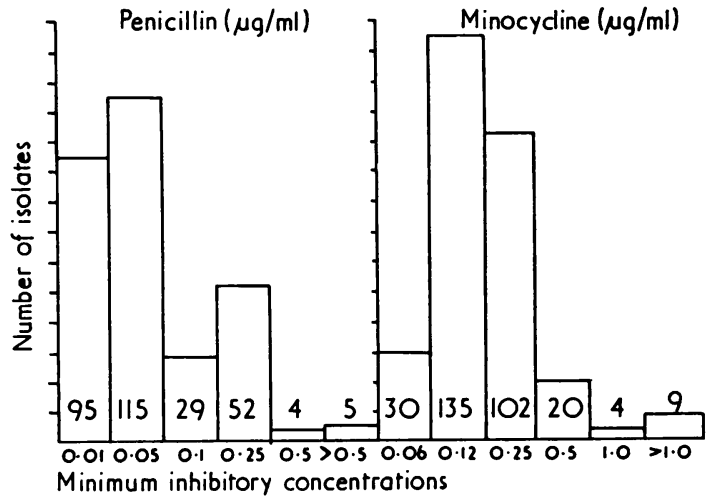

FIGURE No. of isolates at each MIC for Penicillin and Minocycline

Only 210 (70 per cent.) of the strains of $N$. gonorrhoeae were considered as fully sensitive to penicillin (MIC < 0.1); a further 81 strains (27 per cent.) were of reduced sensitivity (MIC 0.1-0.05) and nine ( 3 per cent.) were considered resistant (MIC $\geqslant 0.5$ ). The corresponding figures for minocy cline were 267 ( 89 per cent.), 24 ( 8 per cent.), and nine ( 3 per cent.) respectively for strains fully sensitive $($ MIC $<0.5)$, of reduced sensitivity (MIC $0.5-1 \cdot 0$ ), and resistant $(\mathrm{MIC}>1 \cdot 0)$.

The Table (overleaf) shows the relationship between the penicillin and minocycline sensitivity of the isolates. Of the nine pencillin resistant strains, five were resistant to minocycline $(M I C>1 \cdot 0)$ and three were of reduced sensitivity to this antibiotic. Only one strain was as sensitive as the Oxford Staphylococcus to minocycline.

\section{Discussion}

Unfortunately, since the laboratory investigations were carried out after the clinical trial, it is not 
TABLE Relationship between penicillin and minocycline MICs for 300 isolates of N. gonorrhoeae

\begin{tabular}{|c|c|c|c|c|}
\hline \multirow{2}{*}{$\begin{array}{l}\text { Penicillin } \\
M I C(\mu g . / m l .)\end{array}$} & \multicolumn{4}{|c|}{ Minocycline MIC ( $\mu \mathrm{g} . / \mathrm{ml})}$. \\
\hline & $<0.5$ & $0.5-1.0$ & $>1 \cdot 0$ & Total \\
\hline $\begin{array}{l}<0.1 \\
0.1-0.5 \\
\geqslant 0.5\end{array}$ & $\begin{array}{r}203 \\
63 \\
1\end{array}$ & $\begin{array}{r}7 \\
14 \\
3\end{array}$ & $\begin{array}{l}0 \\
4 \\
5\end{array}$ & $\begin{array}{r}210 \\
81 \\
9\end{array}$ \\
\hline Total & 267 & 24 & 9 & 300 \\
\hline
\end{tabular}

possible to relate these results directly to the results of treatment. It does seem possible, however, that the described failure rate of 6 per cent. might well be related to the numbers of minocycline resistant gonococci in the community at that time. The fact that five of the nine penicillin resistant strains were also resistant to minocycline and that a further three were of reduced sensitivity to this antibiotic suggests that this compound is unlikely to be of value in treating patients known to be infected with penicillin resistant strains of $N$. gonorrhoeae, unless laboratory tests have shown them to belong to the minority minocycline sensitive group. This has similarities with the findings of Kousa and others (1974) who observed more treatment failures with spectinomycin in patients infected with strains of $N$. gonorrhoeae of reduced sensitivity to penicillin.

\section{Summary}

The minimum inhibitory concentrations of penicillin and minocycline were measured on 300 consecutive isolates of $N$. gonorrhoeae from patients attending the Nottingham treatment centre. 210 (70 per cent.) of these were fully sensitive to penicillin (MIC $<0 \cdot 1$ $\mu \mathrm{g} . / \mathrm{ml}$.) and 89 per cent. were fully sensitive to minocycline $(\mathrm{MIC}<0.5 \mu \mathrm{g} . / \mathrm{ml}$.). Of the nine strains resistant to penicillin (MIC $\geqslant 0.5 \mu \mathrm{g} . / \mathrm{ml}$.), eight were also of reduced sensitivity to minocycline.

\section{References}

Duncan, W. C., Glicksman, J. M., Knox, J. M., and HOLDER, W. R. (1971) Brit. F. vener. Dis., 47, 364

KousA, M., LASSUS, A., JÄrVELÄINEN, R., and RENKONEN, O.-V. (1974) Ibid., 50, 291

Pariser, H., and Marino, A. F. (1970) Antimicrob. Agents and Chemother., 10, 211

Phillifs, I., Humphrey, D., Middleton, A., and Nicol, C. S. (1972) Brit. F. vener. Dis., 48, 287

SchofiEld, C. B. S., and MAsterton, G. (1974) Ibid., 50, 303

Shahidullah, M. (1975) Ibid., 51, 97

Thatcher, R. W., Pazin, G., and Domescik, G. (1970) Publ. Hlth Rep. (Wash.), 85, 160

Willcox, R. R. (1974) Brit. F. vener. Dis., 50, 294 